\title{
Distribution of particulate carbohydrate species in the Bay of Bengal
}

\author{
Vishwas B Khodse*, Narayan B Bhosle and V V Gopalkrishna \\ Council of Scientific and Industrial Research, Marine Corrosion and Material Research Division, \\ National Institute of Oceanography, Dona Paula 403 004, Goa, India. \\ *e-mail: vkhodse@nio.org
}

\begin{abstract}
Suspended particulate matter (SPM) of surface seawaters was collected during December 2003 to October 2004 at 10 stations in the Bay of Bengal, and analyzed for particulate organic carbon (POC), total particulate nitrogen (TPN), total particulate carbohydrate (TPCHO) and total particulate uronic acids (TPURA). The concentrations of POC, TPCHO and TPURA varied from 4.80 to $29.12,0.85$ to $4.24,0.09$ to $0.91 \mu \mathrm{M} \mathrm{C}$, respectively. The TPCHO-C and TPURA-C accounted for $6.6-32.5 \%$ and $0.87-3.65 \%$ of POC. The trends observed for the distribution of these compounds were generally similar to those recorded for the distribution of chlorophyll $a$ $(\mathrm{Chl} a$ ). The $\mathrm{C} / \mathrm{N}$ ratios varied from 3.2 to 22.3 with most of the values being $<10$. This suggests that the organic matter was mostly derived from phytoplankton and bacteria. Relatively low $\mathrm{C} / \mathrm{N}$ ratios and high TPCHO yield imply that freshly derived organic matter was present during SWM and FIM. Our data suggest that the quality and quantity of organic matter varied spatially and seasonally.
\end{abstract}

\section{Introduction}

Carbohydrates are the most important constituents produced by phytoplankton during the process of photosynthesis. Typically, carbohydrates comprise more than $40 \mathrm{wt} \%$ of bacteria and $75 \mathrm{wt} \%$ of vascular plants (Moers and Larter 1993), 20-40 wt\% of plankton (Parsons et al 1984b), 13\% of sinking particulate organic carbon (Tanoue and Handa 1987), 3-35\% of suspended particulate organic carbon (Khodse et al 2007), 10-85\% in seawater dissolved organic carbon (DOC) (Pakulski and Benner 1994) and sediment pore water DOC (Burdige et al 2000), and 3-26\% of sedimentary organic carbon (Khodse et al 2008). These compounds are useful substrates for heterotrophic organisms. It appears that the concentration and composition of carbohydrates are influenced by several factors including nutrient levels, composition of organisms, growth phase, etc. Carbohydrates are classified as structural and storage components of both marine and terrestrial organisms. The storage carbohydrates are utilized preferentially. This results in the accumulation of relatively less degradable structural carbohydrates in the degraded organic matter.

In addition to neutral carbohydrates, many marine micro-organisms, terrestrial plants, algae and other organisms produce uronic acids or acidic carbohydrates (Bergamaschi et al 1999; Hung et al 2003). They are also present in dissolved organic matter, particulate matter, and marine sediments (Bergamaschi et al 1999; Hung et al 2003; Khodse et al 2007, 2008). Although present in small amounts, they are involved in many marine processes such as the production of humic substances and mucilaginous aggregates, biofilm formation and bacterial adhesion and detoxification of toxic chemicals and removal of metal ions (Decho 1990).

There are many studies describing the physical, chemical and biological characteristics of the

Keywords. Suspended particulate matter; chlorophyll $a$; particulate organic carbon; C/N ratio; particulate carbohydrates; particulate uronic acids; organic matter, Bay of Bengal. 
Table 1. Details of sample, location, station depth, season and date of sampling in the Bay of Bengal.

\begin{tabular}{cccccccc}
\hline \multirow{2}{*}{$\begin{array}{l}\text { Station } \\
\text { no. }\end{array}$} & Latitude & Longitude & $\begin{array}{c}\text { Depth } \\
(\mathrm{m})\end{array}$ & WM & SPIM & SWM & FIM \\
\hline 1 & $13.02^{\prime} \mathrm{N}$ & $80.54^{\prime} \mathrm{E}$ & 2655 & $22 / 12 / 2003$ & $17 / 04 / 2004$ & $24 / 07 / 2004$ & $13 / 10 / 2004$ \\
2 & $12.14^{\prime} \mathrm{N}$ & $83.03^{\prime} \mathrm{E}$ & 3275 & $23 / 12 / 2003$ & $18 / 04 / 2004$ & $25 / 07 / 2004$ & $13 / 10 / 2004$ \\
3 & $12.25^{\prime} \mathrm{N}$ & $85.00^{\prime} \mathrm{E}$ & 3277 & $23 / 12 / 2003$ & $18 / 04 / 2004$ & $25 / 07 / 2004$ & $13 / 10 / 2004$ \\
4 & $11.49^{\prime} \mathrm{N}$ & $89.05^{\prime} \mathrm{E}$ & 3151 & $24 / 12 / 2003$ & $19 / 04 / 2004$ & $26 / 07 / 2004$ & $14 / 10 / 2004$ \\
5 & $11.25^{\prime} \mathrm{N}$ & $91.54^{\prime} \mathrm{E}$ & 1470 & $24 / 12 / 2003$ & $20 / 04 / 2004$ & $27 / 07 / 2004$ & $14 / 10 / 2004$ \\
6 & $14.04^{\prime} \mathrm{N}$ & $92.56^{\prime} \mathrm{E}$ & 650 & $01 / 01 / 2004$ & - & $05 / 08 / 2004$ & $17 / 10 / 2004$ \\
7 & $15.57^{\prime} \mathrm{N}$ & $91.37^{\prime} \mathrm{E}$ & 2300 & $01 / 01 / 2004$ & - & $05 / 08 / 2004$ & $17 / 10 / 2004$ \\
8 & $18.59^{\prime} \mathrm{N}$ & $89.30^{\prime} \mathrm{E}$ & 1500 & $02 / 01 / 2004$ & - & $06 / 08 / 2004$ & $18 / 10 / 2004$ \\
9 & $20.04^{\prime} \mathrm{N}$ & $89.03^{\prime} \mathrm{E}$ & 1344 & $02 / 01 / 2004$ & - & $06 / 08 / 2004$ & $18 / 10 / 2004$ \\
10 & $20.35^{\prime} \mathrm{N}$ & $88.40^{\prime} \mathrm{E}$ & 145 & $02 / 01 / 2004$ & - & $07 / 08 / 2004$ & $18 / 10 / 2004$ \\
\hline
\end{tabular}

Bay of Bengal (Madhupratap et al 2003; Prasanna Kumar et al 2004, 2007; Sardessai et al 2007; Paul et al 2007, 2008; Fernandes et al 2008). However, there is only one study that deals with the seasonal variation in the characterization of suspended particulate organic matter of the Bay of Bengal (Khodse et al 2007). Studies on the distribution of suspended particulate organic matter provide useful information on the dynamics, nature and fate of organic matter in marine environment. Therefore, in this paper, we assess the seasonal variations in the distribution of particulate organic carbon (POC), total particulate nitrogen (TPN), particulate carbohydrates (TPCHO), and particulate uronic acids (TPURA) along the Chennai to Andaman and Andaman to Kolkata transects in the Bay of Bengal.

\section{Materials and methods}

\subsection{Description of the study area}

Bay of Bengal (BOB) is a semi-enclosed tropical basin located in the northern Indian Ocean. It is bounded by the Indian Peninsula and Sri Lanka on the west and by the Andaman-Nicobar Islands and Burma on the east. The Bay is influenced by reversing monsoons that cause seasonal changes in circulation and weather. Its unique characteristic is the major rivers Ganges, Brahmaputra, Godavari, Krishna, Mahanadi, Pennar and Cauvery drain into the Bay large quantities of fresh water $\left(1.6 \times 10^{12} \mathrm{~m}^{3} \mathrm{yr}^{-1}\right)$ (Subramanian 1993). These rivers introduce $2.0 \times 10^{15} \mathrm{~g}$ of suspended particulate matter into the Bay (Rao 1985). River discharge is expected to add nutrients to the upper layers and increase the biological productivity of the Bay. However, warm sea surface temperature and low salinity lead to strong stratification that prevents transport of nutrients into surface waters. Moreover, the weak winds are unable to break the thermocline. Upwelling has been observed along the western boundary of the Bay (Shetye et al 1991). Cyclones are frequent in the Bay, and can pump nutrients into the surface waters. This results in localized algal blooms (Vinaychandran and Mathew 2003). Phytoplankton biomass measured as $\mathrm{Chl} a$ showed small variation, and diatoms such as Thalassiothrix sp, Rizosolenia sp, and Nitzschia are generally abundant (Paul et al 2007). The average primary production was $9.3 \mathrm{mg} \mathrm{C} \mathrm{m}{ }^{-3}$ day $^{-1}$ and $20 \mathrm{mg} \mathrm{C} \mathrm{m}^{-3}$ day $^{-1}$ in the central Bay and the western Bay (Fernandes et al 2008). Surface primary production was higher during southwest monsoon (SWM) (11-13 $\left.\mathrm{mg} \mathrm{C} \mathrm{m}^{-3} \mathrm{~d}^{-1}\right)$ followed by winter monsoon $(\mathrm{WM})\left(5.5-3.1 \mathrm{mg} \mathrm{C} \mathrm{m}^{-3} \mathrm{~d}^{-1}\right)$ and spring inter monsoon (SPIM) $\left(5-4.4 \mathrm{mg} \mathrm{C} \mathrm{m}^{-3}\right.$ $\mathrm{d}^{-1}$ ) (Jyothibabu et al 2008). Bacteria were abundant and varied from 0.04 to $1.0 \times 10^{9}{\text { cells } l^{-1}}^{-1}$ (Gauns et al 2005). Prasanna Kumar et al (2004, 2007) suggested the importance of cold core eddies in enhancing the biological productivity of the Bay. According to Gauns et al (2005) Chl a, primary production, phytoplankton and zooplankton abundance are several fold lower in the Bay as compared to the Arabian Sea. Many factors including cloud cover, large sediment load, narrow shelf, stratification, etc., are considered to be responsible for the low production in the Bay (Madhupratap et al 2003; Paul et al 2007; Fernandes et al 2008).

\subsection{Experimental methods}

At five selected stations along Chennai to Andaman, and from Andaman to Kolkata routes, 


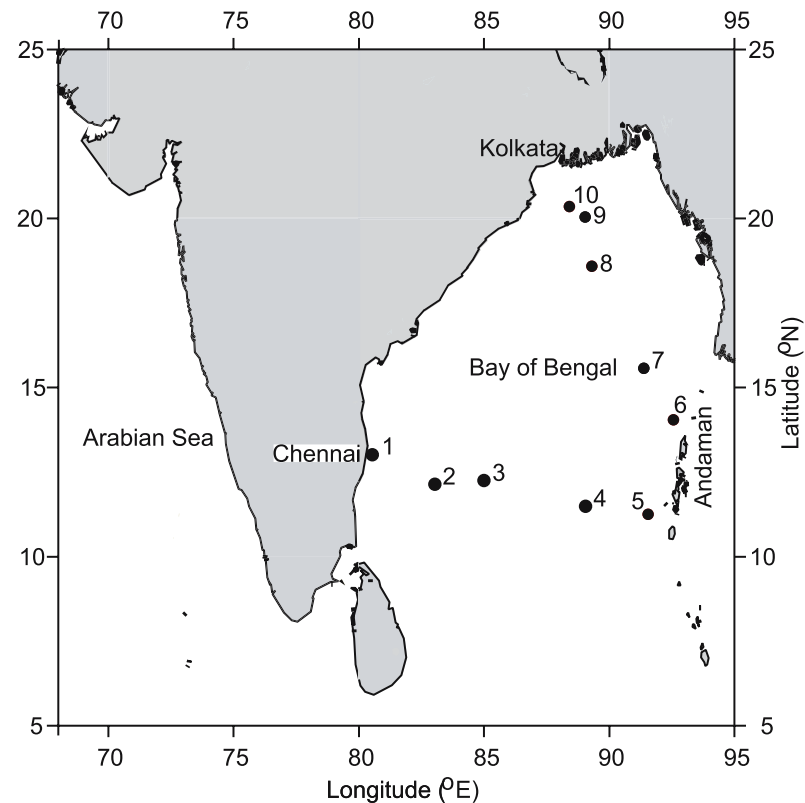

Figure 1. Map showing the location of sampling stations in the Bay of Bengal.

suspended particulate matter (SPM) of surface water was sampled (table 1, figure 1) during winter monsoon (WM), spring inter monsoon (SPIM), southwest monsoon (SWM) and fall inter monsoon (FIM). A clean plastic bucket was used to collect surface seawater. Immediately after collection, a known amount of water sample (4l) was filtered through pre-combusted $\left(450^{\circ} \mathrm{C}, 4 \mathrm{~h}\right)$ glass fiber filter $(47 \mathrm{~mm} \mathrm{GF} / \mathrm{F}, 0.7 \mu \mathrm{m}$ pore size). The SPM collected on the GF/F filter was dried at room temperature and transferred into clean vials and stored at $-20^{\circ} \mathrm{C}$ until analysis. The SPM was analyzed for POC, TPN, TPCHO and TPURA.

\subsection{Analytical methods}

Sea surface temperature (SST) data were obtained from Expendable Bathythermograph (XBT). SST data for SWM were collected from http://dsrs.atmos.umd.edu/DATA/SODA_ 1.4.3.

Sea surface salinity (SSS) was analyzed using auto-analyzer. Weekly data on Chl $a$ abundance during the period December 2003 to October 2004 were derived from SeaWiFS (http://reason. gsfc.nasa.gov/OPS/Giovanni/ocean.seawifs.shtml). POC was analyzed spectrophotometrically by the wet oxidation of carbon with acid dichromate (Parsons et al 1984a). TPN was estimated following the method of Raimbault and Gerd (1991). TPCHO was analyzed by the phenol-sulfuric acid method (Dubois et al 1956), and the TPURA was estimated by the hydroxydiphenyl method (Filisetti-Cozzi and Carpita 1991) as described in Khodse et al (2007). Analytical variability of these methods was $<10 \%$.

\section{Results and discussion}

\subsection{General hydrography}

The distribution of sea surface temperature (SST) and sea surface salinity (SSS) along ChennaiAndaman and Andaman-Kolkata are given in table 2. SST along the Chennai-Andaman transect shows marginal variation during WM, SWM and FIM. However, during SPIM, SST showed an increase from $29.7^{\circ} \mathrm{C}$ off Chennai to $31.4^{\circ} \mathrm{C}$ towards Andaman Sea. Along the Andaman-Kolkata transect, SST showed opposite trend during SWM and FIM. On the other hand, under the influence of winter cooling, SST showed continuous decrease from Andaman $\left(28.0^{\circ} \mathrm{C}\right)$ towards Kolkata $\left(25.9^{\circ} \mathrm{C}\right)$ during WM (Shetye et al 1993; Varkey et al 1996). The SSS showed small changes along the ChennaiAndaman transect (table 2), whereas the SSS generally decreased from station 6 to station 10 along the Andaman-Kolkata transect in SWM and FIM. During the WM, SSS varied from 30.5 to 32.5 along the Andaman-Kolkata transect. It may be noted that under the influence of river runoff and precipitation over the Bay of Bengal, during FIM SSS showed a dramatic decrease from 31.5 at station 6 in the Andaman Sea to 26.7 at station 9 off Kolkata.

\subsection{POC, TPN C/N ratio and Chl a}

The POC and TPN showed seasonal and spatial variation and ranged between $4.80 \mu \mathrm{M} \mathrm{C}$ and $29.12 \mu \mathrm{M} \mathrm{C}$, and 0.31 and $1.52 \mu \mathrm{M} \mathrm{N}$, respectively. Concentrations of POC and TPN observed during this study are comparable with those previously recorded for the Bay (Nandakumar et al 1987; Bhosle et al 1988; Kumar et al 2004; Fernandes et al 2006; Khodse et al 2007). The distribution of POC and TPN along these two transects compares well with the seasonal distribution of $\mathrm{Chl} a$ derived from SeaWiFS (figure 2). The concentrations of POC were generally high during the WM followed by SWM, FIM and SPIM (table 2). TPN also showed small spatial variations, and concentrations were high in SWM and FIM and low in SPIM (table 2). During WM, high concentration $(29.12 \mu \mathrm{M} \mathrm{C})$ of POC was recorded at station 1. Concentrations decreased from station 1 to station 4 along the Chennai-Andaman transect. Similarly, along the Andaman-Kolkata transect, with the exception of station 8 , POC concentration showed small variations. During all the seasons pumping of nutrients in near surface waters by eddies has been observed (Prasanna Kumar, personal communication). Moreover, during WM (11-16 December 2003) cyclone was observed in western Bay of Bengal (Kotal et al 2008). These 
Table 2. Distribution of temperature, salinity, particulate organic carbon (POC), particulate nitrogen (TPN), C/N ratio, total particulate carbohydrates (TPCHO), particulate uronic acids (TPURA) and TPURA/TPCHO ratio in suspended particulate matter of the surface seawater collected at various locations of the Bay of Bengal.

\begin{tabular}{|c|c|c|c|c|c|c|c|c|}
\hline $\begin{array}{l}\text { Station } \\
\text { no. }\end{array}$ & $\begin{array}{c}\text { Temperature } \\
\left({ }^{\circ} \mathrm{C}\right)\end{array}$ & Salinity & $\begin{array}{c}\text { POC } \\
(\mu \mathrm{M} \mathrm{C})\end{array}$ & $\begin{array}{c}\text { TPN } \\
(\mu \mathrm{M} \mathrm{N})\end{array}$ & $\begin{array}{l}\mathrm{C} / \mathrm{N} \\
\text { ratio }\end{array}$ & $\begin{array}{l}\text { TPCHO } \\
(\mu \mathrm{M} \mathrm{C})\end{array}$ & $\begin{array}{l}\text { TPURA } \\
(\mu \mathrm{M} \mathrm{C})\end{array}$ & $\begin{array}{c}\text { TPURA/ } \\
\text { TPCHO } \\
\text { ratio }\end{array}$ \\
\hline \multicolumn{9}{|c|}{ Winter monsoon (WM) } \\
\hline 1 & 28.6 & 33.5 & $29.12 \pm 0.17$ & - & - & $4.24 \pm 0.25$ & $0.91 \pm 0.11$ & 0.23 \\
\hline 2 & 28.4 & 33.4 & $12.07 \pm 0.84$ & - & - & $1.13 \pm 0.08$ & $0.40 \pm 0.04$ & 0.38 \\
\hline 3 & 28.5 & 33.2 & $12.93 \pm 0.30$ & - & - & $0.85 \pm 0.05$ & $0.28 \pm 0.03$ & 0.36 \\
\hline 4 & 28.2 & 33.5 & $11.26 \pm 0.47$ & - & - & $1.14 \pm 0.08$ & $0.15 \pm 0.02$ & 0.14 \\
\hline 5 & 28.3 & 32.6 & $13.14 \pm 0.11$ & - & - & $1.46 \pm 0.03$ & $0.23 \pm 0.02$ & 0.17 \\
\hline 6 & 28.0 & 32.4 & $10.99 \pm 0.52$ & - & - & $1.64 \pm 0.05$ & $0.19 \pm 0.00$ & 0.12 \\
\hline 7 & 27.5 & 30.3 & $13.53 \pm 0.29$ & - & - & $2.10 \pm 0.14$ & $0.27 \pm 0.03$ & 0.14 \\
\hline 8 & 26.5 & 32.5 & $17.76 \pm 0.25$ & - & - & $1.71 \pm 0.03$ & $0.28 \pm 0.02$ & 0.18 \\
\hline 9 & 25.5 & 32.5 & $12.00 \pm 0.11$ & - & - & $1.46 \pm 0.04$ & $0.27 \pm 0.02$ & 0.20 \\
\hline 10 & 25.9 & 30.5 & $12.63 \pm 0.12$ & - & - & $1.79 \pm 0.04$ & $0.33 \pm 0.02$ & 0.20 \\
\hline \multicolumn{9}{|c|}{ Spring inter monsoon (SPIM) } \\
\hline 1 & 29.7 & 35.0 & $4.80 \pm 0.60$ & 0.44 & 9.4 & $1.56 \pm 0.02$ & $0.19 \pm 0.01$ & 0.13 \\
\hline 2 & 30.1 & 34.1 & $6.54 \pm 0.84$ & 0.50 & 11.2 & $1.16 \pm 0.00$ & $0.13 \pm 0.02$ & 0.12 \\
\hline 3 & 30.3 & 32.3 & $6.35 \pm 0.39$ & 0.53 & 10.4 & $1.18 \pm 0.07$ & $0.11 \pm 0.01$ & 0.10 \\
\hline 4 & 30.0 & 32.4 & $7.23 \pm 0.63$ & 0.31 & 19.8 & $1.02 \pm 0.08$ & $0.09 \pm 0.01$ & 0.09 \\
\hline 5 & 31.4 & 32.5 & $6.29 \pm 0.28$ & 0.47 & 11.4 & $1.16 \pm 0.05$ & $0.11 \pm 0.01$ & 0.10 \\
\hline \multicolumn{9}{|c|}{ Southwest monsoon (SWM) } \\
\hline 1 & 30.0 & 33.0 & $7.68 \pm 1.15$ & 0.70 & 9.4 & $1.28 \pm 0.12$ & $0.21 \pm 0.01$ & 0.17 \\
\hline 2 & 29.5 & 33.0 & $8.79 \pm 0.60$ & 0.89 & 8.5 & $1.17 \pm 0.13$ & $0.19 \pm 0.02$ & 0.17 \\
\hline 3 & 29.3 & 32.6 & $11.60 \pm 0.36$ & 0.86 & 11.5 & $0.91 \pm 0.12$ & $0.11 \pm 0.01$ & 0.13 \\
\hline 4 & 28.9 & 32.9 & $7.47 \pm 0.80$ & 1.01 & 6.3 & $1.58 \pm 0.12$ & $0.14 \pm 0.02$ & 0.10 \\
\hline 5 & 28.8 & 33.1 & $6.16 \pm 0.60$ & 0.99 & 5.3 & $1.02 \pm 0.05$ & $0.10 \pm 0.01$ & 0.09 \\
\hline 6 & 29.3 & 32.6 & $11.4 \pm 1.15$ & 1.14 & 8.5 & $1.76 \pm 0.15$ & $0.16 \pm 0.01$ & 0.10 \\
\hline 7 & 29.4 & 32.3 & $9.70 \pm 1.44$ & 1.52 & 5.5 & $1.55 \pm 0.20$ & $0.20 \pm 0.01$ & 0.14 \\
\hline 8 & 29.9 & 31.6 & $14.24 \pm 0.80$ & 1.34 & 9.1 & $2.23 \pm 0.31$ & $0.19 \pm 0.02$ & 0.09 \\
\hline 9 & 30.4 & 31.6 & $12.55 \pm 1.71$ & 0.48 & 22.3 & $1.13 \pm 0.10$ & $0.14 \pm 0.00$ & 0.13 \\
\hline 10 & 30.3 & 31.5 & $11.81 \pm 1.00$ & 1.25 & 8.1 & $1.85 \pm 0.12$ & $0.15 \pm 0.01$ & 0.09 \\
\hline \multicolumn{9}{|c|}{ Fall inter monsoon (FIM) } \\
\hline 1 & 29.5 & 33.7 & $13.00 \pm 0.42$ & 0.55 & 20.0 & $2.43 \pm 0.35$ & $0.14 \pm 0.01$ & 0.06 \\
\hline 2 & 29.3 & 33.8 & $9.38 \pm 0.58$ & 0.68 & 11.8 & $0.91 \pm 0.12$ & $0.19 \pm 0.02$ & 0.22 \\
\hline 3 & 28.7 & 31.9 & $8.29 \pm 1.15$ & 0.55 & 13.0 & $1.11 \pm 0.15$ & $0.14 \pm 0.02$ & 0.13 \\
\hline 4 & 28.9 & 33.3 & $6.51 \pm 0.61$ & 1.39 & 4.0 & $1.02 \pm 0.05$ & $0.11 \pm 0.01$ & 0.12 \\
\hline 5 & 29.1 & 32.8 & $8.11 \pm 0.74$ & 0.61 & 11.4 & $1.44 \pm 0.18$ & $0.11 \pm 0.01$ & 0.08 \\
\hline 6 & 29.3 & 31.5 & $12.68 \pm 1.18$ & 1.16 & 9.4 & $2.51 \pm 0.25$ & $0.14 \pm 0.02$ & 0.06 \\
\hline 7 & 29.1 & 31.2 & $9.44 \pm 1.20$ & 1.42 & 5.7 & $1.82 \pm 0.04$ & $0.15 \pm 0.02$ & 0.09 \\
\hline 8 & 28.8 & 30.6 & $7.93 \pm 1.10$ & 1.26 & 5.4 & $2.00 \pm 0.26$ & $0.28 \pm 0.01$ & 0.15 \\
\hline 9 & 28.8 & 26.7 & $5.69 \pm 0.70$ & 1.52 & 3.2 & $1.03 \pm 0.11$ & $0.23 \pm 0.01$ & 0.24 \\
\hline 10 & 28.8 & 28.0 & $7.62 \pm 0.90$ & 1.29 & 5.1 & $1.21 \pm 0.05$ & $0.15 \pm 0.01$ & 0.14 \\
\hline
\end{tabular}

$-=$ no data; $\pm=$ represent SD of three different samples. Temperature data for the SWM was obtained from the site http://dsrs.atmos.umd.edu/DATA/SODA_1.4.3/.

cyclonic circulation features can bring the nutrients to the surface. Availability of nutrients in near surface waters enhances biological production. This was evident from the SeaWiFS data showing high abundance of Chl $a$ at station 1 in the southern Bay and relatively low concentrations at other stations (figure 2).

During SWM, concentrations of POC and TPN were higher at station $10(11.81 \mu \mathrm{M} \mathrm{C}, 1.25 \mu \mathrm{M} \mathrm{N})$ in northern Bay as compared to station 1 

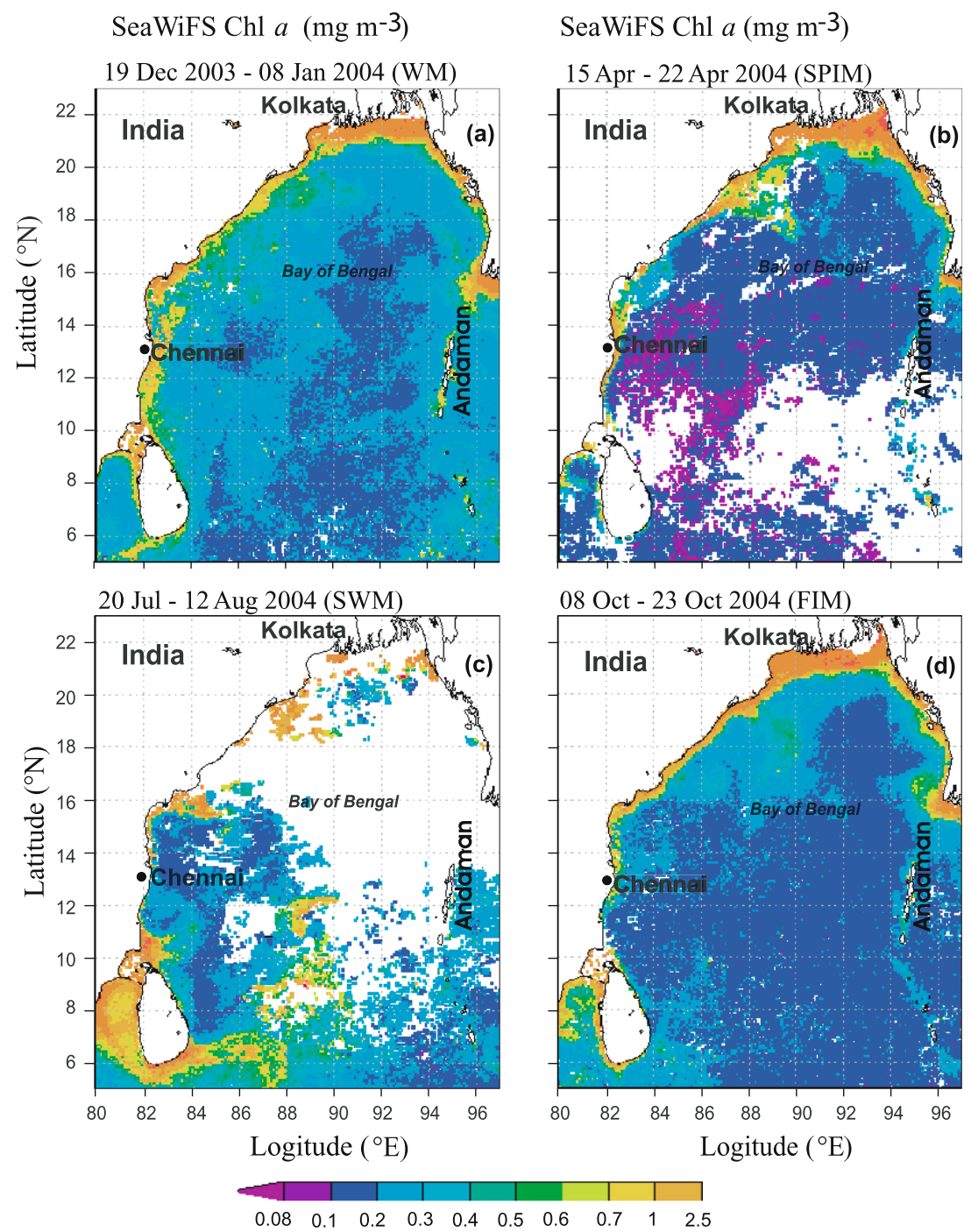

Figure 2. Seasonal variations of weekly SeaWiFS Chl $a$ concentrations $\left(\mathrm{mg} \mathrm{m}^{-3}\right)$ during winter monsoon (WM) (a), spring inter monsoon (SPIM) (b), southwest monsoon (SWM) (c) and fall inter monsoon (FIM) (d) in the Bay of Bengal. Chl $a$ concentration derived from http://reason.gsfc.nasa.gov/OPS/Giovanni/ocean.aqua.shtml.

$(7.68 \mu \mathrm{M} \mathrm{C}, 0.70 \mu \mathrm{MN})$ in the southern Bay. The excess precipitation over evaporation and river run-off freshen up the upper water layers, especially of the northern region of the Bay. River discharge adds nutrients to the upper layers and thus expected to increase biological productivity of the Bay. However, during the SWM, the upper ocean layer is highly stratified. Prasanna Kumar et al $(2004,2007)$ identified cold core eddies during SWM in the Bay of Bengal, and proposed eddy pumping as possible mechanisms of vertical transfer of nutrients across the halocline to the oligotrophic euphotic zone during SWM. This would induce rapid biological uptake, and in turn enhance biological production. Therefore, organic matter production due to nutrient addition by eddy pumping and the inputs of organic matter from rivers may be responsible for the higher concentration of POC and TPN at station 10 during the SWM.

On the other hand, during the FIM, some increase in nitrate and silicate due to fresh water run-off in the north was detected (Prasanna Kumar et al 2007; Sardessai et al 2007). During this period, four cyclonic eddies were observed. The availability of nutrients and improved light condition due to low SPM enhances biological productivity in the north while it was more than double in the south (Prasanna Kumar et al 2007). This was evident from the distribution of POC at station 1 $(13.0 \mu \mathrm{MC})$ in southern Bay and at station 10 $(7.62 \mu \mathrm{MC})$ in the northern Bay. During SPIM, only the Chennai-Andaman transect was operated. During this period, the POC concentrations were relatively lower than those recorded at these locations during SWM and FIM. During the SPIM 

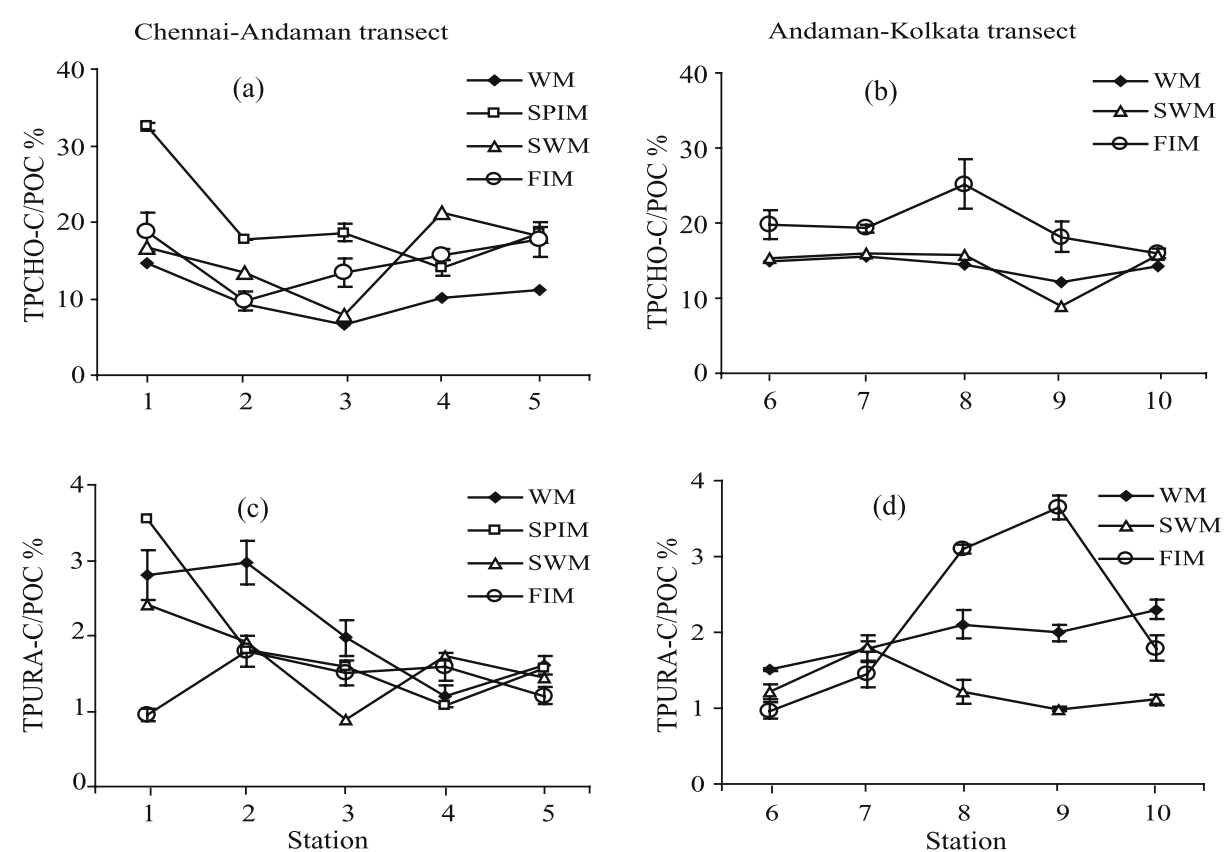

Figure 3. Seasonal and spatial variation of \% TPCHO-C/POC, and \% TPURA-C/POC of the suspended particulate matter at various stations of the Bay of Bengal.

period, the physical forcing is weak (Prasanna Kumar et al 2007; Sardessai et al 2007), and probably because of this, the POC production was relatively low during this period.

The $\mathrm{C} / \mathrm{N}$ ratio is a useful tool to assess the nature of organic matter. The $\mathrm{C} / \mathrm{N}$ ratio varied from 3 to 22 (table 2 , figure $4 \mathrm{~d}$ ). With the exception of a few values, the $\mathrm{C} / \mathrm{N}$ ratio was $<10$ for most of the stations. Moreover, the $\mathrm{C} / \mathrm{N}$ ratio was generally low during SWM for the stations sampled on the Chennai to Andaman transect. Interestingly, the $\mathrm{C} / \mathrm{N}$ ratio was lowest for the stations sampled along the Andaman to Kolkata transect during the FIM. Average $\mathrm{C} / \mathrm{N}$ ratio was high for the SPIM $(12.4 \pm 4.2)$ and relatively low for the SWM $(8.2 \pm 2.4)$, and FIM $(5.7 \pm 2.2)$ (figure $4 \mathrm{~d})$. Marine bacteria and microalgae have a ratio of $<4-6$ (Elser et al 2000). In contrast, the $\mathrm{C} / \mathrm{N}$ ratio of the terrestrial organic matter varied from 20 to 200 (Hedges et al 1986). The low $\mathrm{C} / \mathrm{N}$ values $(<10)$ indicate the presence of relatively fresh organic matter derived from bacteria and microalgae during the SWM and FIM periods. In contrast, high $(12.4 \pm 4.2) \mathrm{C} / \mathrm{N}$ ratio in SPIM indicates the presence of degraded organic matter and/or the influence of terrestrial organic matter in the study area.

\section{$3.3 \mathrm{TPCHO}$}

TPCHO showed some spatial and seasonal variation, and ranged between 0.85 and $4.24 \mu \mathrm{MC}$ (average $=1.53 \pm 0.65 \mu \mathrm{M} \mathrm{C}$ ) (table 2). Except for high concentration at station 1 , TPCHO showed small changes at the stations sampled along the Chennai-Andaman transect (table 2). As compared to the Chennai-Andaman transect, TPCHO concentrations were relatively higher at stations sampled along the Andaman-Kolkata transect. However, spatial variations in the distribution of TPCHO were small at the stations sampled along this transect. During the WM and FIM, station 1 located in the southern Bay showed relatively higher concentration of TPCHO. In contrast, during SWM higher concentration of TPCHO was recorded at station 10 in the northern Bay. In general, these TPCHO trends are in line with those recorded for the distribution of POC, TPN and Chl $a$. TPCHO values observed during the present study are in the range of values earlier reported for the Bay of Bengal (Khodse et al 2007 and the references therein). These values also compare well with those reported from the Red Sea $(2.12-3.14 \mu \mathrm{M} \mathrm{C})$, northern and central Indian Ocean $(0.73-1.5 \mu \mathrm{M} \mathrm{C})$, and western and southern Australian areas of Indian Ocean $(0.4-1.31 \mu \mathrm{M} \mathrm{C})$ (Misic et al 2006).

Contribution of carbohydrate-carbon to bulk organic carbon is defined as the yield. Carbohydrate yield is high for the freshly derived organic matter, and relatively low for the degraded organic matter. Because of this, carbohydrate yield is a useful tool to assess the freshness or the degradation state of organic matter (Skoog and Benner 1997; Khodse et al 2007). In the present study, TPCHO-C accounted for $6.6 \%$ to $32.5 \%$ of POC (figure $3 \mathrm{a}, \mathrm{b}$ ). For the stations sampled along the 
Chennai-Andaman transect, the average TPCHO yield was high $(20.3 \pm 7.0 \%)$ in SPIM, low in WM $(10 \pm 2.9 \%)$, and intermediate during SWM $(15.4 \pm 5.0 \%)$ and FIM $(15.0 \pm 3.6)$, suggesting the presence of fresh organic matter during these seasons (figure 4a). However, in SPIM, high TPCHO yield $(20.3 \pm 7.0 \%)$ was associated with high $\mathrm{C} / \mathrm{N}$ ratio (12.4 \pm 4.1$)$ indicating that the organic matter was influenced by the presence of terrestrial organic matter. Interestingly, along the Chennai-Andaman transect, although the TPCHO yields were similar during SWM and FIM, the average $\mathrm{C} / \mathrm{N}$ ratio was low (8.2) for the former and high (12.0) for the latter (figure $4 \mathrm{~d}$ ). This difference in the $\mathrm{C} / \mathrm{N}$ ratio strongly indicates the presence of relatively more fresh organic matter in the SWM as compared to the FIM at the stations sampled along the Chennai-Andaman transect. For the stations sampled along the Andaman-Kolkata transect TPCHO yields, with exception of a few values, showed small spatial variations. The average yields were similar for the WM $(14.2 \pm 1.2)$ and SWM $(14.3 \pm 2.3)$, and higher $(19.7 \pm 3.4)$ for the FIM (figure 4a). Moreover, the $\mathrm{C} / \mathrm{N}$ ratio of the organic matter was high $(10.7 \pm 6.6)$ for SWM and low $(5.7 \pm 2.2)$ for the FIM (figure $4 \mathrm{~d}$ ). From these data it is evident that during FIM, relatively fresh organic matter was present at these stations along the Andaman-Kolkata transect. This conclusion was also supported by the fairly good inverse correlation $(r=-0.552, p<0.01)$ relation between the TPCHO yields and the $\mathrm{C} / \mathrm{N}$ ratios.

Carbohydrate production by micro-organisms is influenced by phase of growth, nutrient status, phytoplankton species composition and/or bacterial activity (Morris 1981; D'Souza and Bhosle 2001). Phytoplankton composition varied spatially and seasonally, but generally, diatoms were most abundant in the Bay of Bengal (Paul et al 2007). Diatoms are known to produce higher amounts of carbohydrates during the stationary phase of growth and under nutrient deficient conditions (D'Souza and Bhosle 2001). In surface waters nutrients were rarely present (Sardessai et al 2007). Therefore, variations in some of these factors may have been involved in controlling the abundance of carbohydrates in the Bay.

\subsection{TPURA}

Acidic carbohydrates such as uronic acids are produced by many marine organisms including bacteria, fungi, phytoplankton, microalgae, plants and animals. Some commercially important plant structural polysaccharides, such as pectin and alginic acid are almost entirely composed of glycosidically bound uronic acids. In aquatic environments, uronic acids are produced by algae
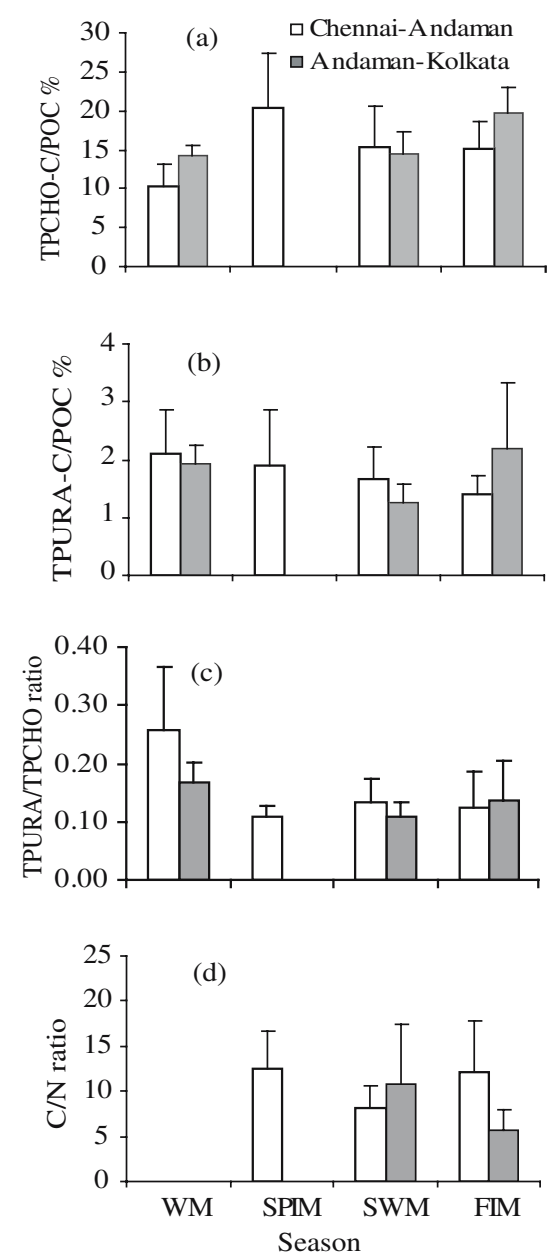

Figure 4. Seasonal variation of the average \% TPCHO-C/POC (a), \%TPURA-C/POC (b), average TPURA/TPCHO ratio (c) and average (weight/weight) $\mathrm{C} / \mathrm{N}$ ratio (d) for the stations sampled along the ChennaiAndaman and Andaman-Kolkata transect in the Bay of Bengal.

and bacteria during low nutrient condition and higher metal stress (Decho 1990). They are surfaceactive compounds, and are known to perform many important functions in marine environments (Decho 1990). For example, they are involved in the removal of toxic metal ions, detoxification of toxic chemicals, adsorption of dissolved organic matter and microbial adhesion and biofilm development, etc. (Decho 1990). Although numerous functions have been described to uronic acids, we know little about their distribution, dynamics and sources in marine environments. TPURA concentrations in the Bay of Bengal showed large variations, and ranged from 0.09 to $0.91 \mu \mathrm{MC}$ (average $=0.20 \pm 0.14 \mu \mathrm{M} \mathrm{C}$ ) during the period of study (table 2). For both transects, concentrations of TPURA were higher during the WM due to biological production as seen from high Chl $a$ distribution (figure 2). Along the ChennaiAndaman transect, TPURA concentration was 
highest at station 1 , and the concentrations generally decreased from station 1 to station 5 along this transect during all seasons. While along the Andaman-Kolkata transect, the TPURA concentration showed a small increase from station 6 to station 10 during the WM while small differences were observed during other periods of sampling (table 2). TPURA concentration was greater at station 1 in the southern Bay, and was lower at station 10 in the northern Bay during WM and the SWM periods. While no particular trend was evident during the FIM. Generally, the trends observed for the distribution of TPURA were similar to those recorded for the POC and TPCHO.

The contribution of TPURA-C to POC is defined as yield. The yields varied from 0.87 to $3.5 \%$ along the Chennai-Andaman transect (figure 3c, d). Along this transect, the yields decreased from station 1 to station 5 with some exceptions (figure 3c). The average TPURA yield was highest $(2.1 \%)$ during WM and decreased in SPIM (1.9\%), SWM (1.7\%), and FIM $(1.4 \%)$ (figure $4 \mathrm{~b})$. On the other hand, for the Andaman-Kolkata transect, the average yield was higher $(1.9 \%)$ during WM that decreased (1.3\%) during the SWM, and increased $(2.2 \%)$ again in FIM (figure 4b). TPURA/TPCHO ratio provides useful information on the relative distribution of these compounds. The ratio generally was high at station 1 , and decreased up to station 5 along the Chennai-Andaman transect during SPIM, SWM, and FIM (table 2). The average TPURA/TPCHO ratio was higher $(0.26 \pm 0.11)$ during the $\mathrm{WM}$ and decreased during the SPIM $(0.11 \pm 0.02)$, SWM $(0.13 \pm 0.04)$ and FIM $(0.12 \pm 0.06)$ (figure 4c). Similarly, along the Andaman-Kolkata transect, the ratio showed small increase (0.12 to 0.20$)$ from station 6 to station 10, whereas no consistent trend was recorded during SWM and FIM periods (table 2). The average TPURA/TPCHO ratio was high $(0.17 \pm 0.03)$ during the WM and relatively low in SWM $(0.11 \pm 0.02)$ and FIM $(0.14 \pm 0.07)$ (figure 4c). High TPURA/TPCHO indicates that the organic matter was relatively degraded. This is also supported by low TPCHO yield during WM. The decrease TPURA/TPCHO ratio indicates higher production of carbohydrates relative to TPURA by phytoplankton. Both the concentrations and the yields are in the range of values reported earlier from different environments (Bergamaschi et al 1999; Hung et al 2001, 2003; Khodse et al 2007). The production of TPURA by micro-organisms is influenced by many factors, especially nutrients and the composition of microorganisms (Decho 1990; Hung et al 2003). Both these factors showed spatial and seasonal variation and thus may have influenced the abundance of
TPURA in the Bay (Paul et al 2007; Sardessai et al 2007; Fernandes et al 2008).

\section{Conclusions}

Seasonal and spatial variations in the distribution of POC, TPN, TPCHO, and TPURA were monitored in the surface waters of the Bay of Bengal. These constituents of the organic matter varied seasonally and spatially during the period of observation. Concentrations of POC, TPN, TPCHO and TPURA were relatively higher during the WM period. This distribution compares well with the distribution of Chl $a$. However, the low TPCHO yield, high TPURA yield and high TPURA/TPCHO ratio suggest the presence of poor quality organic matter during WM. Whereas in SPIM, the organic matter was characterized with high TPCHO yield and high $\mathrm{C} / \mathrm{N}$ ratio $(>10)$ indicating that it was degraded and/or influenced by the presence of terrestrial organic matter. On the other hand, high TPCHO yields and low $\mathrm{C} / \mathrm{N}$ ratio during the FIM and SWM, implies that the organic matter was freshly produced during these periods. Our data showed strong seasonal variation in the quality of organic matter in Bay.

\section{Acknowledgements}

The authors are grateful to Dr Satish Shetye, the Director NIO, for encouragement and facilities. The first author (VK) is grateful to the INCOIS for financial support. We also thank Mr Ravidas Naik, Mr Gourish, Mr Suprit Kumar and Ms Nisha Kurian for their help in the collection of samples. We are grateful to the captains and crew of the ships of the Shipping Corporation of India (SCI) for their help in sampling. This is NIO contribution no. 4498.

\section{References}

Bergamaschi B A, Walters J S and Hedges J 1999 Distributions of uronic acids and $O$-methyl sugars in sinking and sedimentary particles in two coastal marine environments; Geochim. Cosmochim. Acta 63 413-425.

Bhosle N B, Dhople V M and Wagh A B 1988 Distribution of particulate organic carbon in the central Arabian Sea; Proc. Indian Acad. Sci. (J. Earth Syst. Sci.) 97 35-47.

Burdige D J, Skoog A and Gardner K 2000 Dissolved and particulate carbohydrates in contrasting marine sediments; Geochim. Cosmochim. Acta 64 1029-1041.

Decho A W 1990 Microbial exopolymer secretions in the ocean environments, their role(s) in food webs and marine processes; Oceanogr. Mar. Biol. Annu. Rev. 28 73-153.

D'Souza F and Bhosle N B 2001 Variation in the composition of carbohydrates in the Dona Paula Bay (west of India) during May/June 1998; Oceanol. Acta 24 221-237. 
Dubois M, Gilles K A, Hamilton J K, Rebers P A and Smith F 1956 Colorimetric method for determination of sugars and related substances; Anal. Chem. 28 350-356.

Elser J J, Fagan W F, Denno R F, Dobberfuhl D R, Folarin A, Huberty A, Interlandi S, Kilham S S, McCauley E, Schulz K L, Siemann E H and Sterner R W 2000 Nutritional constraints in terrestrial and freshwater food web; Nature 408 578-580.

Fernandes L, D'Souza F, Matondkar S P G and Bhosle N B 2006 Amino sugars in suspended particulate matter from the Bay of Bengal during the summer monsoon of 2001; J. Earth Syst. Sci. 115 363-370.

Fernandes V, Ramaiah N, Paul J T, Sardessai S, Babu R J and Gauns M 2008 Strong variability in bacterioplankton abundance and production in central and western Bay of Bengal; Mar. Biol. 153 975-985.

Filisetti-Cozzi T M C C and Carpita N C 1991 Measurement of uronic acids without interference from neutral sugars; Anal. Biochem. 197 157-162.

Gauns M, Madhupratap M, Ramaiah N, Jyothibabu R, Fernandes V, Paul J T and Prasanna Kumar S 2005 Comparative accounts of biological productivity characteristics and estimates of carbon fluxes in the Arabian Sea and Bay of Bengal; Deep-Sea Res. II 52 2003-2017.

Giovanni Ocean Color Time-Series Online Visualization and Analysis; http://reason.gsfc.nasa.gov/OPS/Giovanni/ ocean.aqua.shtml

Hedges J I, Clark W A, Quay P D, Richey J E, Devol A H, Santos U and De M 1986 Composition and fluxes of particulate organic material in the Amazon River; Limnol. Oceanogr. 31 717-738.

Hung C-C, Tang D, Warnken K W and Santschi P H 2001 Distributions of carbohydrates, including uronic acids, in estuarine waters of Galveston Bay; Mar. Chem. $\mathbf{7 3}$ 305-318.

Hung C-C, Guo L, Santschi P H, Alvarado-Quiroz N and Haye J 2003 Distributions of carbohydrate species in the Gulf of Mexico; Mar. Chem. 81 119-135.

Jyothibabu R, Madhu N V, Maheswaran P A, Jayalakshmy K V, Nair K K C and Achuthankutty C T 2008 Seasonal variation of microzooplanton $(20-200 \mu \mathrm{m})$ and it's possible implications on the vertical carbon flux in the western Bay of Bengal; Cont. Shelf Res. 28(6) $737-755$.

Khodse V B, Fernandes L, Gopalkrishna V V, Bhosle N B, Fernandes V, Matondkar S G P and Bhushan R 2007 Distribution and seasonal variation of concentrations of particulate carbohydrates and uronic acids in the northern Indian Ocean; Mar. Chem. 103 327-346.

Khodse V B, Fernandes L, Bhosle N B and Sardessai S 2008 Carbohydrates, uronic acids and alkali extractable carbohydrates in contrasting marine and estuarine sediments: Distribution, size fractionation and partial chemical characterization; Org. Geochem. 39 265-283.

Kotal S D, Bhowmik S K R, Kundu P K and Das A K 2008 A statistical cyclone intensity prediction (SCIP) model for the Bay of Bengal; J. Earth Syst. Sci. 117(2) 157-168.

Kumar S, Ramesh R, Bhosle N B, Sardessai S and Sheshshayee M S 2004 Natural isotopic composition of nitrogen in suspended particulate matter in the Bay of Bengal; Biogeosci. 1 63-70.

Madhupratap M, Gauns M, Ramaiah N, Prasanna Kumar S, Muraleedharan P M, de Sousa S N, Sardessai S and Muraleedharan U 2003 Biogeochemistry of the Bay of Bengal: Physical, chemical and primary productivity characteristics of the central and western Bay of Bengal during summer monsoon 2001; Deep-Sea Res. II 50 881-896.
Misic C, Castellano M, Fabiano M, Ruggieri N, Sagginomo V and Povero P 2006 Ectoenzymatic activity in surface waters: A transect from the Mediterranean Sea across the Indian Ocean to Australia; Deep-Sea Res. 53 1517-1532.

Moers M E and Larter S R 1993 Neutral monosaccharides from a hypersaline tropical environment: Applications to the characterization of modern and ancient ecosystems; Geochim. Cosmochim. Acta 57 3063-3071.

Morris I 1981 Photosynthetic products, physiological state and phytoplankton growth; Can. Bull. Fish. Aquat. Sci. $20183-102$.

Nandakumar K, Venkat K and Bhosle N B 1987 Distribution of particulate organic carbon in the central Bay of Bengal; Proc. Indian Acad. Sci. (J. Earth Syst. Sci.) 96 189-193.

Pakulski J D and Benner R 1994 Abundance and distribution of carbohydrates in the Ocean; Limnol. Oceanogr. 39 930-940.

Parsons T R, Maita Y and Lalli C M 1984a A Manual of Chemical and Biological Methods for Seawater Analysis; (Oxford: Pergamon).

Parsons T R, Takahashi M and Hargrave B 1984b Biological Oceanographic Processes 3rd edn. (New York: Pergamon Press).

Paul J T, Ramaiah N, Gauns M and Fernandes V 2007 Preponderance of a few diatom species among the highly diverse microphytoplankton assemblages in the Bay of Bengal; Mar. Biol. 152 63-75.

Paul J T, Ramaiah N and Sardessai S 2008 Nutrient regimes and their effect on distribution of phytoplankton in the Bay of Bengal; Mar. Environ. Res. 66(3) 337-344.

Prasanna Kumar S, Nuncio M, Narvekar J, Kumar A, Sardessai S, de Sousa S N, Gauns M, Ramaiah N and Madhupratap M 2004 Are eddies nature's trigger to enhance biological productivity in the Bay of Bengal; Geophys. Res. Lett. 29 2235, doi: 10.1029/2002GL016013.

Prasanna Kumar S, Nuncio M, Ramaiah N, Sardessai S, Narvekar J, Fernandes V and Paul T 2007 Eddy-mediated biological productivity in the Bay of Bengal during fall and spring intermonsoons; Deep-Sea Res. I 54(9) 1619-1640.

Raimbault P and Gerd S 1991 A semiquantitative wet oxidation method for the determination of particulate organic nitrogen collected on filters; Limnol. Oceanogr. 36 405-408.

Rao Ch M 1985 Distribution of suspended particulate matter in the waters of eastern continental margin of India; Indian J. Mar. Sci. 14 14-19.

Sardessai S, Ramaiah N, Prasanna Kumar S and de Sousa S N 2007 Influence of environmental forcings on the seasonality of dissolved oxygen and nutrients in the Bay of Bengal; J. Mar. Res. 65(2) 301-316.

Shetye S R, Shenoi S S C, Gouveia A D, Michael G S, Sundar D and Nampoothiri G 1991 Wind-driven coastal upwelling along the western boundary of the Bay of Bengal during the southwest monsoon; Cont. Shelf Res. 11 1397-1408.

Shetye S R, Gouveia A D, Shenoi S S C, Sundar D, Michael G S and Nampoothiri G 1993 The western boundary current of the seasonal subtropical gyre in the Bay of Bengal; J. Geophys. Res. 98 945-954.

Skoog A and Benner R 1997 Aldoses in various size fractions of marine organic matter: implications for carbon cycling; Limnol. Oceanogr. 42 1803-1810.

Subramanian V 1993 Sediment load of Indian Rivers; Curr. Sci. $64928-930$.

Tanoue E and Handa N 1987 Monosaccharide composition of marine particles and sediments from the Bering Sea and northern North Pacific; Oceanol. Acta 10 91-99. 
Varkey M J, Murty V S N and Suryanarayana A 1996 Physical oceanography of the Bay of Bengal and Andaman Sea; In: Oceanography and Marine biology, An Annual Review, (eds) Ansell A D, Gibson R N and Margaret Barnes, 34 p.
Vinaychandran P N and Mathew S 2003 Phytoplankton bloom in the Bay of Bengal during northeast monsoon and its intensification by cyclones; Geophys. Res. Lett. 30(11) 1572, doi: 10.1029/2002GL016717.

MS received 2 June 2008; revised 22 December 2008; accepted 6 January 2009 